\title{
In vitro and in vivo anti-aging effects of compounds isolated from Artemisia iwayomogi
}

\author{
Kyung Young Kim ${ }^{1}$, Eun Ju Lee ${ }^{2}$, Wan Kyunn Whang ${ }^{3^{*}}$ and Cho Hi Park ${ }^{4^{*}}$
}

\begin{abstract}
In Korean folk medicine, Artemisia iwayomogi has largely been employed for the improvement of diabetic complications and hepatic function as well as in the treatment of female diseases and skin whitening. Accordingly, the present study sought to assess cosmeceutical activity of Artemisia iwayomogi. Through activity-guided fractionation, scopolin (Al-1), 2,4-dihydroxy-6methoxy-acetophenone 4-O-B-D-glucoside (Al-2), scopoletin (Al-3), kaempferol-3-O-methyl ether (Al-4) and luteolin (Al-5) were isolated from ethyl acetate and water fractions of Artemisia iwayomogi. Of them, Al-4 and Al-5 exhibited strong antioxidative and whitening effects. In addition, Al-1, Al-3, Al-4, and Al-5 demonstrated considerable antiwrinkle performances. According to results of quantitative analysis of compounds isolated from Artemisia iwayomogi, scopolin (Al-1) is a major component of Artemisia iwayomogi. Moreover, O/W type cream made by water fraction which included scopolin showed unwrinkling effect for 8 weeks when it was applied to face in an in vivo study. Specific contributions of Artemisia iwayomogi were as follows: Al-1, $1.21 \mathrm{mg} / \mathrm{g} ; \mathrm{Al}-2,0.26 \mathrm{mg} /$ g; Al-3, $0.38 \mathrm{mg} / \mathrm{g}$; Al- $4,0.01 \mathrm{mg} / \mathrm{g}$; and Al-5, $0.04 \mathrm{mg} / \mathrm{g}$.
\end{abstract}

Keywords: Artemisia iwayomogi, Scopolin, Anti-wrinkle effect, Cosmeceuticals

\section{Introduction}

Artemisia iwayomogi, also called Haninjin or Deowijiki, is a native plant that naturally grows across Korea beginning in spring (Jung et al., 2008). Traditional Korean medicine has widely employed Artemisia iwayomogi for its anti-tumor, immune-modulating, anti-mutagenic, anti-oxidant, anti-bacterial, anti-fungal, anti-pyretic, diuretic, liver protective, choleretic and diabetic complications relieving effects among others (Seo \& Yun, 2008; Lee et al., 2013; Lee et al., 2017). Globally, the Artemisia genus comprises ca. 400 different plant species. Within the framework of traditional medicine, Artemisia iwayomogi has been used as herbal medicine to treat jaundice caused by acute hepatitis elicited by humidity. It is also used to treat urination problems, itchy skin, chronic hepatitis, hepatic sclerosis and fever (Jang et al., 2012). Artemisia iwayomogi has remarkable heat-lowering and

\footnotetext{
* Correspondence: whang-wk@cau.ac.kr; chohi@sungshin.ac.kr

${ }^{3}$ Pharmaceutical Botany Laboratory, College of Pharmacy, Chung-Ang

University, Heukseok-dong, Dongjak-gu, Seoul 156-756, Republic of Korea

${ }^{4}$ Department of Beauty Industry, Sungshin Women's University, Dobong-ro

76 Ga-gil, Gangbuk-gu, Seoul 01133, Republic of Korea

Full list of author information is available at the end of the article
}

humidity-removing effects (Ahn et al., 2003). Numerous studies have demonstrated that Artemisia iwayomogi fractions and ingredients isolated from Artemisia iwayomogion have protective and anti-inflammatory functions for hepatic cells. However, research on cosmetic effects of Artemisia iwayomogi is scarce. To bridge this gap in the literature, using activity-guided fractionation, five compounds were isolated from Artemisia iwayomogi extract and their anti-oxidation, whitening and anti-aging effects were investigated in the present study. Furthermore, an $\mathrm{O} / \mathrm{W}$ formulation cream that contained water fraction from Artemisia iwayomogi was used in facial skin test. Results demonstrated that Artemisia iwayomogi could be effectively used as a natural ingredient for cosmeceuticals.

\section{Materials and methods \\ General experimental procedures \\ UV spectra were determined on an Optizen 2120 UV spectrophotometer (Korea). NMR spectra were recorded on a Varian Gemini 2000 spectrometer (USA) with $1 \mathrm{H}$ - NMR $600 \mathrm{MHz}$ and 13C-NMR $150 \mathrm{MHz}$. FAB-MS}


spectra were measured on a VG 70-VSEQ spectrometer (UK). Silica gel (70-230 mesh, Merck, Germany), Sephadex LH-20 (25-100 $\mu \mathrm{m}$, Pharmacia, Sweden) and ODS gel (400-500 mesh, Waters, USA) were used for column chromatography (CC).

\section{Extraction and isolation}

Artemisia iwayomogi $(20 \mathrm{~kg})$ was extracted with ethanol with a sonicator at room temperature. Ethanol extract $(1.45 \mathrm{~kg})$ was evaporated to dryness in vacuum. This crude extract was suspended in water and then divided into four fractions: hexane $(280 \mathrm{~g})$, dichloromethane $(150 \mathrm{~g})$, ethyl acetate $(485 \mathrm{~g})$ and water fraction $(420 \mathrm{~g})$. From ethyl acetate and water fractions which showed potent anti-oxidant activities, five compounds were obtained. The water fraction was fractionated to XAD-4 using water, $30 \%, 50 \%$, and $100 \%$ methanol as eluent. Eluted product with $50 \% \mathrm{MeOH}$ was subjected to Sephadex gel CC using 30\% $\mathrm{MeOH}$ to yield compound 1 (4.5 g) and compound $2(860 \mathrm{mg})$. The ethyl acetate fraction was subjected to Silica gel CC using DCM:MeOH (10:1) to yield five fractions. Fraction 2 was subjected to Silica gel $\mathrm{CC}$ using $\mathrm{CHCl}_{3}: \mathrm{MeOH}(80: 1)$ to yield compound 3 (376 mg), compound 4 (58 mg), and compound 5 (150 $\mathrm{mg})$. These compounds were confirmed based on their spectroscopic values $\left({ }^{1} \mathrm{H}-\mathrm{NMR},{ }^{13} \mathrm{C}-\mathrm{NMR}, \mathrm{FAB}-\mathrm{MS}\right.$, UV) that were consistent with literature values: scopolin (Bayoumi et al., 2008), 2,4-dihydroxy-6-methoxy-acetophenone-4-O- $\beta$ $D$-glucopyranoside (Singh et al., 1997), scopoletin (Bayoumi et al., 2010), kaempferol-3-O-methyl ether (Urbatsch et al., 1975), and luteolin (Kim et al., 2000).

\section{In vitro biological activities $D P P H$ radical scavenging activity}

DPPH radical scavenging activity was measured using the method described by Hatano et al. (Hatano et al., 1989). Briefly, $180 \mu \mathrm{L}$ of DPPH solution $(0.1 \mathrm{mM}$ in ethanol) and $20 \mu \mathrm{L}$ of compound solution were vortex-mixed and incubated at $37^{\circ} \mathrm{C}$ for $30 \mathrm{~min}$. Absorbance at 517 $\mathrm{nm}$ was then measured. Ascorbic acid was used as positive control. DPPH radical scavenging activity was expressed as $\mathrm{IC}_{50}$.

\section{Superoxide scavenging activity}

Superoxide scavenging activity was determined spectrophotometrically by continuously measuring uric-acid formation at $590 \mathrm{~nm}$ with NBT (blue tetrazolium chloride) as substrate (Lu \& Foo, 2000). Xanthine oxidase assay consisted of $395 \mu \mathrm{L}$ reaction mixture containing $50 \mathrm{mM}$ potassium phosphate buffer ( $\mathrm{pH} 7.4), 0.6 \mathrm{mM}$ hypoxanthine, $0.2 \mathrm{mM} \mathrm{NBT}$, and $1 \mathrm{mM}$ EDTA as substrate solution. Thereafter, $5 \mu \mathrm{L}$ of sample solution and $100 \mu \mathrm{L}$ of xanthine oxidase $(100 \mathrm{mU} / \mathrm{mL})$ were added to the substrate solution. The reaction mixture was incubated at $37^{\circ} \mathrm{C}$ for $20 \mathrm{~min}$. Trolox, a well-known xanthine oxidase inhibitor, was then used to stop the reaction. Superoxide scavenging activity was expressed as $\mathrm{IC}_{50}$.

\section{Tyrosinase inhibition activity}

Tyrosinase inhibition activity was measured using the method described by $\mathrm{Li}$ et al. (Li et al., 2003). Briefly, $450 \mu \mathrm{L}$ of mixture containing $1.7 \mathrm{mM} \mathrm{L}$-tyrosine and 10 $\mathrm{mM}$ sodium phosphate buffer ( $\mathrm{pH} 6.8$ ) was added to $5 \mu \mathrm{L}$ of sample solution and $250 \mathrm{U} / \mathrm{mL}$ of tyrosinase. The reaction mixture was incubated at $37^{\circ} \mathrm{C}$ for $60 \mathrm{~min}$, and the absorbance was measured at $475 \mathrm{~nm}$. Kojic acid was used as a positive control. Tyrosinase inhibition activity was expressed as $\mathrm{IC}_{50}$.

\section{Elastase inhibition activity}

Elastase inhibition activity was measured using the method described by Yamauch et al. (Yamauchi et al., 2000). Briefly, $500 \mu \mathrm{L}$ of $50 \mathrm{mM}$ Tris- $\mathrm{HCl}$ buffer (pH 8.0) was added to $100 \mu \mathrm{L}$ of the sample solution and $500 \mu \mathrm{L}$ of $100 \mathrm{mM}$ porcine pancreas elastase. The mixture was incubated at $37^{\circ} \mathrm{C}$ for $5 \mathrm{~min}$. Thereafter, $1.0 \mathrm{~mL}$ of 0.8 $\mathrm{mMN}$-Succinyl-(Ala) $)_{3}-p$-nitroanilide was injected into the mixture, after which the mixture was left at $37^{\circ} \mathrm{C}$ for $30 \mathrm{~min}$. The absorbance was measured at $405 \mathrm{~nm}$. Ursolic acid was used as positive control. Elastase inhibition activity was expressed as $\mathrm{IC}_{50}$.

\section{Collagenase inhibition activity}

Collagenase inhibition activity was determined according to the method reported by Assem (Assem, 2007). Briefly, $320 \mu \mathrm{L}$ of calcium chloride $(10 \mathrm{mM})$ in $0.2 \mathrm{M}$ Tris- $\mathrm{HCl}$ buffer ( $\mathrm{pH}$ 7.5), $200 \mu \mathrm{L}$ of Clostridium histolyticum collagenase $(0.4 \mathrm{mg} / \mathrm{mL})$, and $200 \mu \mathrm{L}$ of sample solution were mixed and pre-incubated at $37^{\circ} \mathrm{C}$ for $15 \mathrm{~min}$. In the next step, $200 \mu \mathrm{L}$ of N-[3-(2-Furyl) acryloyl]-Leu-Gly-Pro-Ala $(1 \mathrm{mM})$ was added and the mixture was incubated at $37^{\circ} \mathrm{C}$ for $20 \mathrm{~min}$. Absorbance was measured at $324 \mathrm{~nm}$. Disodium-EDTA was used as positive control. Collagenase inhibition activity was expressed as $\mathrm{IC}_{50}$.

\section{In vivo anti-aging effect \\ Subjects and study protocol}

A total of 21 women volunteers aged 30 to 50 years (average age, $39.19 \pm 6.02$ years) living in Seoul or Gyunggi-do, Republic of Korea, who started to develop wrinkles or already had wrinkles were recruited. They provided consent form to participate in this study. They were not allowed to use anti-wrinkling cosmetics, skin esthetics, plastic surgeries, or other prescribed clinical test cosmetics during the trial period. These volunteers had no history of skin diseases. They underwent a patch test which was performed for 8 weeks. Before the trial, a 
patch test was performed to the inner side of the arm of participant using water fraction cream of Artemisia iwayomogi with some ingredients known as skin irritants such propylene glycol, sodium lauryl sulfate (SLS), and liquid paraffin to determine their skin response to the product and product safety. After confirming safety, control patch was applied to the corner of the left eye while a cream that contained 1\% water fraction of Artemisia iwayomogi was applied to the right corner of the right eye. Left and right side corners of their crow's feet $2 \mathrm{~cm}$ away from the outer corner of eye were then observed. They used the cream after face washing as the final phase of basic make-up in the morning and evening for 8 weeks. During test time, they avoided exposure to ultraviolet radiation from the sun. If skin irritation occurred, they would stop using the cream as requested.

\section{Preparation of cosmetics}

Ingredients of $\mathrm{O} / \mathrm{W}$ formulation cream are shown in Table 1. Part A and part B were dissolved in distilled water which was heated up to $80^{\circ} \mathrm{C}$, respectively. After that, part B was added into part $\mathrm{A}$ and the mixture was blended at $3500 \mathrm{rpm}$ for 5 min using a homogenizing mixer. Then, part $C$ was added into the mixture of $\mathrm{A}$ and $\mathrm{B}$ and cooled down to $45^{\circ} \mathrm{C}$. Part D was then mixed with A, B, and C at $2500 \mathrm{rpm}$

Table 1 Prescription of O/W-type formulation cosmetics

\begin{tabular}{|c|c|c|}
\hline No. & Ingredient & Contents (\%) \\
\hline \multirow[t]{7}{*}{ A } & Distilled water & 60.14 \\
\hline & 1,3 Butylene glycol & 4.0 \\
\hline & Glycerin & 4.0 \\
\hline & Xanthan Gum & 0.05 \\
\hline & Carbopol 940 (2\%) & 10 \\
\hline & Disodium EDTA & 0.01 \\
\hline & Methyl paraben & 0.1 \\
\hline \multirow[t]{12}{*}{ B } & Stearic acid & 2 \\
\hline & Cetyl alcohol & 2.5 \\
\hline & Macademia nut oil & 7 \\
\hline & Squalane & 3 \\
\hline & Lecithin & 0.3 \\
\hline & Cyclopentasiloxane & 1 \\
\hline & Dimethicone & 0.4 \\
\hline & Glycerol monostearate & 2 \\
\hline & Glyceryl stearate & 1.6 \\
\hline & Sorbitan sesquioleate & 1.2 \\
\hline & Butyl paraben & 0.1 \\
\hline & Ethyl paraben & 0.1 \\
\hline$C$ & Triethanolamine & 0.4 \\
\hline D & Perfume & - \\
\hline Total & & 100 \\
\hline
\end{tabular}

Table $2{ }^{13} \mathrm{C}-\mathrm{NMR}$ spectral data of Al 1 3 $\left(\mathrm{DMSO}-d_{6}\right)$

\begin{tabular}{llll}
\hline Carbon No. & Compound 1 & Compound 2 & Compound 3 \\
\hline 2 & 160.9 & 166.4 & 161.1 \\
3 & 113.7 & 97.1 & 112.1 \\
4 & 144.6 & 162.6 & 144.8 \\
5 & 110.2 & 91.3 & 109.9 \\
6 & 146.5 & 163.6 & 145.0 \\
7 & 150.3 & & 151.5 \\
8 & 103.4 & & 103.1 \\
9 & 149.3 & & 149.9 \\
10 & 112.7 & & 110.0 \\
glu-1 & 100.1 & 100.1 & \\
glu-2 & 73.5 & 73.5 & \\
glu-3 & 77.5 & 77.7 & \\
glu-4 & 70.0 & 70.1 & \\
glu-5 & 77.2 & 77.0 & \\
glu-6 & 61.1 & 61.1 & \\
OMe & 56.5 & 56.3 & \\
\hline A-1 & & &
\end{tabular}

Al-1 scopolin, Al-2 2,4-dihydroxy-6-methoxy-acetophenone-4-O-B-Dglucopyranoside, Al-3 scopoletin

for $2 \mathrm{~min}$ and cooled down to $30^{\circ} \mathrm{C}$. The test cream was then added with $1 \%$ water fraction of Artemisia iwayomogi. $\mathrm{O} / \mathrm{W}$ formulation cream alone was used as control.

\section{Measurement and analysis method of wrinkles}

For quantitative evaluation of wrinkles, a Skin Visiometer SV600 (Courage \& Khazaka, Germany) was used

Table $3{ }^{13} \mathrm{C}$-NMR spectral data of Al 4 5 (DMSO- $d_{6}$ )

\begin{tabular}{lll}
\hline Carbon No. & Compound 4 & Compound 5 \\
\hline 2 & 151.1 & 164.3 \\
3 & 148.4 & 102.8 \\
4 & 182.2 & 182.0 \\
5 & 164.1 & 161.8 \\
6 & 99.2 & 99.2 \\
7 & 164.6 & 164.5 \\
8 & 94.5 & 94.2 \\
9 & 157.7 & 157.6 \\
10 & 104.1 & 103.3 \\
$1^{\prime}$ & 121.9 & 119.4 \\
$2^{\prime}$ & 120.8 & 113.7 \\
$3^{\prime}$ & 103.6 & 146.1 \\
$4^{\prime}$ & 161.8 & 150.1 \\
$5^{\prime}$ & 116.2 & 116.4 \\
$6^{\prime}$ & 110.5 & 121.9 \\
OMe & 56.3 & \\
\hline
\end{tabular}

Al-4 kaempferol-3-O-methyl ether, Al-5 luteolin 
to quantify and analyze the depth of fine wrinkles. It represents the depth of wrinkles numerically using a replica of wrinkled model through a light source. The replica was made to use a silicon base (polymer) and a hardener (catalyst) at a ratio of 1:1 with pressure applied for $10-15 \mathrm{~s}$ to prevent air bubbles. Thus, a portion of the prepared mixture was hardened after stuck to the measurement site to make a replica. Transmitted light through the replica was converted into digital information with a video digitalization unit and a graphic card embedded in the PC. The transmitted light was displayed based on the gray value which was in the range of 256 gray value $(0=$ black, $256=$ white $)$. The depth range was $20 \sim 30 \mu \mathrm{m}$. Positions of wrinkles were digitized using an arbitrary parameter for the shape and depth of wrinkles (R1, R2, R3, R4, and R5). R1 is skin roughness which is the maximum and minimal grayness. $\mathrm{R} 2$ is maximum roughness that a wrinkle is divided into five sections and calculated R1 respectively after divided wrinkles. R2 has the highest wrinkle value. R3 is average roughness which is the maximum and minimum grayness. R4 is smoothness depth that a centerline is drawn on the side view of wrinkles. It is calculated that the area meets the centerline. $\mathrm{R} 5$ is the arithmetic average roughness. It pertains to the mean depth of a wrinkle.

\section{Identification of compounds}

Scopolin (AI-1) White amorphous powder; UV-Vis $\lambda_{\max }(\log \varepsilon) \mathrm{nm}: 339,288$ and 227; FAB-MS $m / z: 355$ $[\mathrm{M}+\mathrm{H}]^{+} .{ }^{1} \mathrm{H}-\mathrm{NMR}\left(600 \mathrm{MHz}, \mathrm{DMSO}-d_{6}\right): \delta 7.94(1 \mathrm{H}, \mathrm{d}$, $J=9.6 \mathrm{~Hz}, \mathrm{H}-4), \delta 7.27(1 \mathrm{H}, \mathrm{s}, \mathrm{H}-5), \delta 7.14(1 \mathrm{H}, \mathrm{s}, \mathrm{H}-8)$, $\delta 6.31(1 \mathrm{H}, \mathrm{d}, J=9.6 \mathrm{~Hz}, \mathrm{H}-3), \delta 5.07(1 \mathrm{H}, \mathrm{d}, J=7.2 \mathrm{~Hz}$, anomeric-H(Glu-1)), $\delta 3.80\left(3 \mathrm{H}, \mathrm{s}, \mathrm{OCH}_{3}\right) ;{ }^{13} \mathrm{C}-\mathrm{NMR}$ $\left(125 \mathrm{MHz}, \mathrm{DMSO}-d_{6}\right)$ (Table 2).

\section{2,4-dihydroxy-6-methoxy-acetophenone-4-O- $\beta$ - $D$ -} glucopyranoside (AI-2) Yellow amorphous crystal; UV-Vis $\lambda_{\max }(\log \varepsilon)$ nm: 283; FAB-MS $m / z: 345$ $[\mathrm{M}+\mathrm{H}]^{+} .{ }^{1} \mathrm{H}-\mathrm{NMR}\left(600 \mathrm{MHz}, \mathrm{DMSO}-d_{6}\right): \delta 7.08(1 \mathrm{H}, \mathrm{d}$, $J=1.8 \mathrm{~Hz}, \mathrm{H}-3), \delta 6.12(1 \mathrm{H}, \mathrm{d}, J=1.8 \mathrm{~Hz}, \mathrm{H}-5), \delta 4.94$ $(1 \mathrm{H}, \mathrm{d}, J=7.4 \mathrm{~Hz}$, anomeric- $\mathrm{H}(\mathrm{Glu}-1)), \delta 3.82(3 \mathrm{H}, \mathrm{s}$, $\left.\mathrm{OH}_{3}\right)$ and $\delta 2.55\left(3 \mathrm{H}, \mathrm{s}, \mathrm{OCH}_{3}\right) ;{ }^{13} \mathrm{C}-\mathrm{NMR}(125 \mathrm{MHz}$, DMSO- $d_{6}$ ) (Table 2).

Scopoletin (AI-3) Yellow amorphous crystal; UV-Vis $\lambda_{\max }(\log \varepsilon) \mathrm{nm}: 344$ and 228; FAB-MS $m / z: 193$ $[\mathrm{M}+\mathrm{H}]^{+} .{ }^{1} \mathrm{H}-\mathrm{NMR}\left(600 \mathrm{MHz}\right.$, methanol- $\left.d_{6}\right): \delta 7.87(1 \mathrm{H}$, d, $J=9.6 \mathrm{~Hz}, \mathrm{H}-4), \delta 7.18(1 \mathrm{H}, \mathrm{s}, \mathrm{H}-5), \delta 6.75(1 \mathrm{H}, \mathrm{s}, \mathrm{H}-$ 8), $\delta 6.19(1 \mathrm{H}, \mathrm{d}, J=9 \mathrm{~Hz}, \mathrm{H}-3)$ and $\delta 3.79(3 \mathrm{H}, \mathrm{s}$, $\left.\mathrm{OCH}_{3}\right) ;{ }^{13} \mathrm{C}-\mathrm{NMR}\left(125 \mathrm{MHz}\right.$, methanol- $d_{6}$ ) (Table 2).

Kaempferol-3-O-methyl ether (AI-4) Yellow amorphous crystal; UV-Vis $\lambda_{\max }(\log \varepsilon) \mathrm{nm}$ : 344; FAB-MS $m / z$ :
Table 4 HPLC analysis conditions of Al 1 3

\begin{tabular}{|c|c|c|c|}
\hline Detector & \multicolumn{3}{|l|}{ UV (280 nm) } \\
\hline Column & \multicolumn{3}{|c|}{ AKZO NOBEL. KR100-5C18 (4.6×250 mm) } \\
\hline \multirow[t]{7}{*}{ Mobile phase } & \multicolumn{3}{|c|}{$\mathrm{A}-$ Water; $\mathrm{B}-\mathrm{CH}_{3} \mathrm{CN}$} \\
\hline & Time & A (\%) & B (\%) \\
\hline & 0 & 70 & 30 \\
\hline & 30 & 70 & 30 \\
\hline & 40 & 30 & 70 \\
\hline & 45 & 70 & 30 \\
\hline & 60 & 70 & 30 \\
\hline Flow rate & \multicolumn{3}{|l|}{$1.0 \mathrm{~mL} / \mathrm{min}$} \\
\hline Injection volume & \multicolumn{3}{|l|}{$20 \mu \mathrm{L}$} \\
\hline
\end{tabular}

$301[\mathrm{M}+\mathrm{H}]^{+} .{ }^{1} \mathrm{H}-\mathrm{NMR}\left(600 \mathrm{MHz}, \mathrm{DMSO}-d_{6}\right): \delta 12.81$ $(1 \mathrm{H}, \mathrm{s}, \mathrm{OH}), \delta 8.03\left(2 \mathrm{H}, \mathrm{d}, J=8.8 \mathrm{~Hz}, \mathrm{H}-2^{\prime}, 6^{\prime}\right), \delta 7.02$ $\left(2 \mathrm{H}, \mathrm{d}, J=8.8 \mathrm{~Hz}, \mathrm{H}-3^{\prime}, 5^{\prime}\right), \delta 6.50(1 \mathrm{H}, \mathrm{d}, J=1.8 \mathrm{~Hz}, \mathrm{H}-$ $8), \delta 6.26(1 \mathrm{H}, \mathrm{d}, J=1.8 \mathrm{~Hz}, \mathrm{H}-6)$ and $\delta 3.87(3 \mathrm{H}, \mathrm{s}$, $\left.\mathrm{OCH}_{3}\right) ;{ }^{13} \mathrm{C}-\mathrm{NMR}\left(125 \mathrm{MHz}, \mathrm{DMSO}-d_{6}\right)$ (Table 3).

Luteolin (AI-5) Yellow amorphous crystal; UV-Vis $\lambda_{\max }$ $(\log \varepsilon) n m: 349 ;$ FAB-MS $m / z: 287[\mathrm{M}+\mathrm{H}]^{+} .{ }^{1} \mathrm{H}-\mathrm{NMR}$ $\left(600 \mathrm{MHz}, \mathrm{DMSO}-d_{6}\right): \delta 6.16(1 \mathrm{H}, \mathrm{d}, J=2.4 \mathrm{~Hz}, \mathrm{H}-6), \delta$ $6.43(1 \mathrm{H}, \mathrm{d}, J=1.8 \mathrm{~Hz}, \mathrm{H}-8), \delta 6.61(1 \mathrm{H}, \mathrm{s}, \mathrm{H}-3), \delta 6.87$ $\left(1 \mathrm{H}, \mathrm{d}, J=8.4 \mathrm{~Hz}, \mathrm{H}-5^{\prime}\right), \delta 7.37(1 \mathrm{H}, \mathrm{dd}, J=2.4,8.4 \mathrm{~Hz}$, H-6') and $\delta 7.38\left(1 \mathrm{H}, \mathrm{d}, J=2.4 \mathrm{~Hz}, \mathrm{H}-2^{\prime}\right) ;{ }^{13} \mathrm{C}-\mathrm{NMR}$ $\left(125 \mathrm{MHz}, \mathrm{DMSO}-d_{6}\right)$ (Table 3).

\section{Statistical analysis}

Activity results are expressed as means \pm standard deviation (SD). All statistical analyses were performed using Statistical Package for Social Sciences (SPSS for Windows ver. 19.0). A $p$ value of $<0.05$ was considered statistically significant.

\section{HPLC analysis}

For the analysis of contents and patterns of compounds isolated from Artemisia iwayomogi, conditions for the

Table 5 HPLC analysis conditions of Al 4 5

\begin{tabular}{llll}
\hline Detector & UV $(340 \mathrm{~nm})$ & \\
Column & AKZO NOBEL. KR100-5C18 $(4.6 \times 250 \mathrm{~mm})$ \\
Mobile phase & A-0.1\% acetic acid; B- $\mathrm{CH}_{3} \mathrm{CN}$ & \\
& Time & A (\%) & B (\%) \\
& 0 & 70 & 30 \\
& 30 & 70 & 30 \\
& 40 & 30 & 70 \\
& 45 & 70 & 30 \\
Flow rate & 60 & 70 & 30 \\
Injection volume & $1.0 \mathrm{~mL} / \mathrm{min}$ & & \\
\hline
\end{tabular}


Table 6 IC 50 values for activity by compounds from Artemisia iwayomogi

\begin{tabular}{|c|c|c|c|c|c|}
\hline $\begin{array}{l}\text { IC } C_{50} \text { of Activity } \\
(\mu \mathrm{M})\end{array}$ & DPPH radical scavenging & Superoxide scavenging & Tyrosinase inhibition & Elastase inhibition & Collagenase inhibition \\
\hline$\overline{\mathrm{Al}-1}$ & $207.79 \pm 1.06$ & $20.10 \pm 0.97$ & $56.57 \pm 0.91$ & $96.83 \pm 1.02$ & $1.88 \pm 0.87$ \\
\hline $\mathrm{Al}-2$ & $817.28 \pm 0.62$ & $28.45 \pm 0.38$ & $80.92 \pm 4.85$ & $189.71 \pm 2.12$ & $5.05 \pm 2.10$ \\
\hline $\mathrm{Al}-3$ & $147.22 \pm 1.41$ & $14.92 \pm 1.68$ & $7.03 \pm 2.17$ & $38.20 \pm 0.73$ & $2.30 \pm 1.75$ \\
\hline Al-4 & $102.92 \pm 0.97$ & $7.51 \pm 1.57$ & $12.18 \pm 2.18$ & $46.17 \pm 2.93$ & $2.67 \pm 1.33$ \\
\hline $\mathrm{Al}-5$ & $24.34 \pm 1.22$ & $5.75 \pm 1.21$ & $10.18 \pm 2.63$ & $45.35 \pm 1.91$ & $1.97 \pm 1.07$ \\
\hline Positive con. & $28.82 \pm 0.83^{a}$ & $11.83 \pm 0.10^{b}$ & $9.40 \pm 3.83^{c}$ & $66.26 \pm 0.91^{d}$ & $2.60 \pm 1.25^{\mathrm{e}}$ \\
\hline
\end{tabular}

Al-1 scopolin, Al-2 2,4-dihydroxy-6-methoxy-acetophenone-4-O-B-D-glucopyranoside, Al-3 scopoletin, Al-4 kaempferol-3-O-methyl ether, Al-5 luteolin. ${ }^{\text {A Ascorbic }}$ acid, ${ }^{b}$ trolox, ${ }^{c}$ kojic acid, ${ }^{d}$ ursolic acid, ${ }^{e}$ EDTA. All values are mean \pm SD of triplication

HPLC system (Waters Associates, USA) were established. For the analysis, Artemisia iwayomogi was pulverized and filtered using a grade no. 50 filter.

Then, $1.0 \mathrm{~g}$ of filtered Artemisia iwayomogi was sonicated in $30 \mathrm{~mL}$ ethanol, extracted three times in repetition and filtered through a $0.45-\mu \mathrm{m}$-membrane filter. This filtered liquid was used as the test solution. In addition, $1.0 \mathrm{mg}$ taken from each isolated compound of $\mathrm{I} \sim \mathrm{V}$ was dissolved in $10 \mathrm{~mL}$ methanol and used as standard solution. The test and standard solution were tested and their contents were measured with HPLC analysis conditions (Tables 4 and 5).

\section{Results and discussion}

Antioxidant activity Antioxidant activities of isolated compounds were measured using DPPH and superoxide scavenging activity assays with xanthine oxidase and an

Table 7 The change of skin roughness

\begin{tabular}{llllll}
\hline Classification & Left & Right & $t$ & $p$ \\
\hline R1 & 0 week & $0.270 \pm 0.02$ & $0.271 \pm 0.025$ & 0.65 & 0.83 \\
& 4th week & $0.260 \pm 0.057$ & $0.243 \pm 0.037$ & 0.088 & 0.23 \\
& 8th week & $0.246 \pm 0.017$ & $0.223 \pm 0.030$ & 0.071 & $0.001^{*}$ \\
R2 $\quad$ o week & $0.219 \pm 0.037$ & $0.217 \pm 0.025$ & 0.15 & 0.877 \\
& 4th week & $0.194 \pm 0.028$ & $0.186 \pm 0.044$ & 0.166 & 0.427 \\
& 8th week & $0.191 \pm 0.019$ & $0.160 \pm 0.016$ & 0.548 & $0.012^{*}$ \\
R3 $\quad$ o week & $0.131 \pm 0.015$ & $0.129 \pm 0.011$ & 0.42 & 0.451 \\
& 4th week & $0.123 \pm 0.018$ & $0.113 \pm 0.023$ & 0.427 & 0.105 \\
& 8th week & $0.113 \pm 0.018$ & $0.099 \pm 0.019$ & 0.544 & $0.011^{*}$ \\
R4 $\quad$ 0 week & $0.101 \pm 0.018$ & $0.106 \pm 0.026$ & 0.138 & 0.518 \\
& 4th week & $0.100 \pm 0.039$ & $0.084 \pm 0.024$ & 0.127 & 0.116 \\
& 8th week & $0.101 \pm 0.024$ & $0.076 \pm 0.015$ & 0.021 & $0.002^{*}$ \\
R5 $\quad$ 0 week & $0.042 \pm 0.013$ & $0.041 \pm 0.009$ & 0.289 & 0.863 \\
& 4th week & $0.040 \pm 0.021$ & $0.035 \pm 0.010$ & $0.005^{*}$ & 0.317 \\
& 8th week & $0.033 \pm 0.010$ & $0.027 \pm 0.007$ & 0.514 & $0.017^{*}$ \\
\hline
\end{tabular}

*Significant difference between left and right $p<0.05, n=21$ antioxidative activity test using ABTS. In the DPPH scavenging assay, luteolin was found to have a potent antioxidative activity in a dose-dependent manner. In the superoxide scavenging assay, luteolin and kaempferol-3-O-methyl ether showed potent antioxidative activity that was stronger than the positive control (see Table 6). As reported in a previous study (Nguyen et al., 2004), luteolin has an antioxidant activity that can cause direct inhibition of xanthin oxidase activity.

Whitening activity To investigate the whitening effect by mushroom tyrosinase inhibition activity, L-tyrosine was used as a substrate. Among different compounds, scopoletin, luteolin, and kaempferol-3-O-methyl ether showed significant tyrosinase inhibition activities, with $\mathrm{IC}_{50}$ values of $7.03,10.18$ and $12.18 \mu \mathrm{M}$, respectively (Table 6).

Anti-wrinkle activity In the elastase inhibitory assay, scopoletin, luteolin, and kaempferol-3-O-methyl ether showed significant elastase inhibition activities, with $\mathrm{IC}_{50}$ values of $38.20,45.35$, and $46.17 \mu \mathrm{M}$, respectively, all of which were stronger than the positive control (Table 6). Compounds scopolin, luteolin scopoletin, and kaempferol-3-O-methyl ether showed remarkable collagenase inhibition activities, higher than disodium-EDTA (Table 6). As reported in a previous study, scopoletin has the efficacy of promoting type I collagen synthesis in normal human fibroblast in PICP assay (Lee et al., 2006).

Table 8 The contents (mg/g) of Al-1 5 weight by HPLC

\begin{tabular}{ll}
\hline Components & Contents \\
\hline Al-1 & $1.21 \pm 0.07$ \\
Al-2 & $0.26 \pm 0.01$ \\
Al-3 & $0.38 \pm 0.04$ \\
Al-4 & $0.01 \pm 0.01$ \\
Al-5 & $0.04 \pm 0.02$
\end{tabular}

Al-1 scopolin, Al-2 2,4-dihydroxy-6-methoxy-acetophenone-4-O-B-Dglucopyranoside, Al-3 scopoletin, Al-4 kaempferol-3-O-methyl ether, Al-5 luteolin 
<smiles>COc1cc2ccc(=O)oc2cc1OC(C)(C)C</smiles>

Scopolin<smiles>COc1cc2ccc(=O)oc2cc1O</smiles><smiles>COc1c(-c2ccc(O)cc2)oc2cc(O)cc(O)c2c1=O</smiles>

Kaempferol-3-O-methyl ether<smiles>O=c1cc(-c2ccc(O)c(O)c2)oc2cc(O)cc(O)c12</smiles>

Luteolin<smiles>O=[R6]O[GeH3]</smiles>

2, 4- dihydroxy- 6- methoxy- acetophenone $4-O$ - $\beta$ - $D$ - glucopyranoside

Fig. 1 Structures of the compounds $1-5$

\section{Analysis of wrinkles with a Skin Visiometer}

Analysis results with a Skin Visiometer SV600 showed anti-wrinkle effect after using cosmetics that contained water fraction of Artemisia iwayomogi for 8 weeks to the right side of face. The control was applied to the left side of face. Wrinkle replica measurement results of R1, R2, $\mathrm{R} 3, \mathrm{R} 4$, and R5 were obtained using the skin visiometer. For each parameter, the lower the value, the better the wrinkle index (Table 7).

\section{Quantitative analysis of isolated compounds}

Analytical conditions were established using an HPLC reverse-phase column for the five components isolated from ethyl acetate and water fractions. Contents of components were as follows: scopolin, 1.14-1.28 mg/g; 2,4-dihydroxy-6methoxy-acetophenone-4-O- $\beta$-D-glucopyranoside, $0.25-0.27$ $\mathrm{mg} / \mathrm{g} ; \quad$ scopoletin, $\quad 0.34-0.42 \mathrm{mg} / \mathrm{g}$; kaempferol-3-O-methyl ether, 0.00-0.02 mg/g; and luteolin, 0.02-0.06 mg/g (Table 8). Scopolin and scopoletin were found to be major components of Artemisia iwayomogi. Thus, they can be considered to be eligible as index ingredients for herbal medicine and extracts of Artemisia iwayomogi.

\section{Conclusion}

In Korean traditional medicine, Artemisia iwayomogi is routinely used to improve hepatic functioning, to fight against female diseases, for skin whitening and so on. From ethanol extract of the aerial part of Artemisia iwayomogi, hexane, dichloromethane, ethyl acetate, and water fractions were obtained with solvent-fractionating method. An experiment was performed in order to measure antioxidative activities of the extract and its four fractions using both DPPH and ABTS tests. In addition, superoxide-scavenging activity was investigated using xanthine oxidase. Tyrosinase inhibition activity was assessed in order to investigate the whitening effect. Elastase and collagenase inhibition activities were also measured to evaluate anti-aging effect. Results showed that the antioxidative activities of ethyl acetate and water fraction were increased in a concentration-dependent manner. In addition, significant skin whitening and antiwrinkle effects were observed.

Materials used in this study were isolated from ethyl acetate and water fractions according to activity-guided fractionation. Column chromatography was performed using silica gel, ODS and Sephadex LH-20 gel for both ethyl acetate and water fractions. Six components were isolated and their structures were subsequently identified using the following techniques: 1H-NMR, 13C-NMR, UV spectra, and FAB-MS. HPLC reverse-phase column technique was used in order to establish analytical conditions for the five ingredients. Following this, their 
contents were assessed. Content results were as follows: scopolin, $1.14-1.28 \mathrm{mg} / \mathrm{g} ; \quad 2,4$-dihydroxy 6-methoxyacetophenone-4-O- $\beta$-D-glucopyranoside, $0.33-0.35 \mathrm{mg} /$ g; scopoletin, $2.07-2.15 \mathrm{mg} / \mathrm{g}$; kaempferol-3-O-methyl ether, 0-0.02 mg/g; and luteolin, 0.02-0.06 mg/g (Fig. 1). Scopoletin was determined as a major ingredient of $\mathrm{Ar}$ temisia iwayomog. Results demonstrate that the above ingredients are able to be applied as index ingredients.

An anti-wrinkle $\mathrm{O} / \mathrm{W}$ type cosmetic was created using water fraction containing scopolin. This component was used due to its high activity and productivity. During the period of eight weeks, subjects applied the cosmetic to a pre-designated area around their eyes. Within this time, the anti-wrinkling effect of the cosmetic was evaluated. There was an observed change in the height of the wrinkles during the study period. This demonstrates that the water fraction of Artemisia iwayomogi has significant anti-aging effect.

Compound-I was identified as scopolin, compound-II as 2,4-dihydroxy-6-methoxy-acetophenone-4-O- $\beta$-D-glucoside, compound-III as scopoletin, compound-IV as kaempferol-3-O-methyl ether, compound-V as luteolin, and compound-VI as genkwanin. From these isolated components, scopoletin and luteolin were found to have significant antioxidative and whitening activities. In addition, scopolin, scopoletin, and luteolin were found to have remarkable anti-aging effects.

This is the first study to investigate the anti-wrinkle effect of compounds isolated from Artemisia iwayomogi using elastase and collagenase inhibitory assays. Based on results of this study, it can be concluded that Artemisia iwayomogi has the potential to be used as a key material for cosmeceuticals aimed at consumers who are looking for skin whitening and anti-aging products.

\begin{abstract}
Abbreviations
${ }^{13} \mathrm{C}-\mathrm{NMR}$ : Carbon nuclear magnetic resonance; ${ }^{1} \mathrm{H}-\mathrm{NMR}$ : Proton nuclear magnetic resonance; ABTS: 2,2'-Azino-bis (3-ethylbenzothiazoline-6-sulphonic acid); Al: Artemisia iwayomogi; Al-1: Scopolin; Al-2: 2,4-Dihydroxy-6-methoxy-

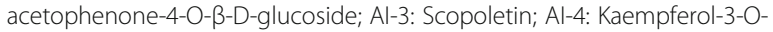
methyl ether; Al-5: Luteolin; Al-6: Genkwanin; CC: Column chromatography; $\mathrm{CHCl}_{3}$ : Chloroform; DCM: Dichloromethane; DMSO: Dimethyl sulfoxide; DPPH: 2,2-Diphenyl-1-picrylhydrazyl; EA: Ethyl acetate;

EDTA: Ethylenediamine-N, N, N', N'-tetraacetic acid; FAB-MS: Fast atom bombardment mass spectrometry; HEX: Hexane; HPLC: High-performance liquid chromatography; $\mathrm{MeOH}$ : Methanol; NBT: Nitroblue tetrazolium test; O/ W: Oil in water; ODS gel: Octadecylsilyl gel; PICP: Carboxyl-terminal propeptide of type I procollagen; R1: Skin roughness; R2: Maximum roughness; R3: Average roughness; R4: Smoothness depth; R5: Arithmetic average roughness; SD: Standard deviation; SLS: Sodium lauryl sulfate; SPSS: Statistical Package for Social Science; UV: Ultraviolet
\end{abstract}

\section{Acknowledgements}

This research was supported by a grant 18172MFDS206 from Ministry of Food and Drug Safety in 2018.

\section{Authors' contributions}

K-KY extracted and isolated the compounds. L-EJ contributed to make the sample of cosmetics and attempted to the volunteer. P-CH assisted the revision of the manuscript and W-WK managed and designed the research project. All authors read and approved the final manuscript.

\section{Funding}

The funding sponsors had no role in the design of the study; collection, analyses, or interpretation of the data; writing of the manuscript; or the decision to publish the results.

Availability of data and materials

Please contact author for data requests.

\section{Competing interests}

The authors declare that they have no competing interests.

\section{Author details}

'Department of Beautycare, Yong-In SongDam College, Yongin, Republic of Korea. ${ }^{2}$ Department of Beauty Stylist, Yeonsung University, Anyang, Republic of Korea. ${ }^{3}$ Pharmaceutical Botany Laboratory, College of Pharmacy,

Chung-Ang University, Heukseok-dong, Dongjak-gu, Seoul 156-756, Republic of Korea. ${ }^{4}$ Department of Beauty Industry, Sungshin Women's University,

Dobong-ro 76 Ga-gil, Gangbuk-gu, Seoul 01133, Republic of Korea.

Received: 23 July 2019 Accepted: 15 October 2019

Published online: 10 December 2019

\section{References}

Ahn H, Kim JY, Lee HJ, Kim YK, Ryu JH. Inhibitors of inducible nitric oxide synthase expression from Artemisia iwayomogi. J Arch Pharm Res. 2003;26: $301-5$.

Assem T (2007) Development of functional oligopeptides for their application in cosmeceutical and food industries, M. S. Dissertation, Andong National University, Andong-si, Gyeongbuk, Korea

Bayoumi SAL, Rowan MG, Beeching JR, Blagbrough IS. Constituents and secondary metabolite natural products in fresh and deteriorated cassava roots. J Phytochemistry. 2010;71(5-6):598-604.

Bayoumi SAL, Rowan MG, Blagbrough IS, Beeching JR. Biosynthesis of scopoletin and scopolin in cassava roots during post-harvest physiological deterioration: The E-Z-isomerisation stage. J Phytochemistry. 2008;69(17):2928-36.

Hatano T, Edamatsu R, Hiramatus M, Mori A, Fujita YT, Yasuhara T, Okuda T. Effects of the interaction of tannins with co-existing substances IV. Effects of tannins and related polyphenols on superoxide anion radical, and on 1,1diphenyl-2-picrylhydrazyl radical. J Chem Pharm Bull. 1989;37:2016.

Jang WS, Kim YS, Seol IC. Antioxidant and lipid-lowering effects of Artemisia capillaris on a Rat Model of Hyperlipidemia. Kor J Orient Med. 2012;33(2): $11-24$.

Jung MJ, Yu Y, Heo SI, Wang MH. Antioxidant and anticancer activities of extract from Artemisia capillaries. Kor J Pharmacogn. 2008:39(3):194-8.

Kim NM, Kim J, Chung HY, Choi JS. Isolation of luteolin 7-O-rutinoside and esculetin with potential antioxidant activity from the aerial parts of Artemisia Montana. J Arch Pharm Res. 2000;23(3):237-9.

Lee JN, Kim SW, Yoo YK, Lee GT, Lee KK. Anti-wrinkle effect of Morinda citrifolia extracts. J Soc Cosmet Sci Korea. 2006;32(4):227-31.

Lee $\mathrm{SH}$, Ding Y, Yan XT, Kim YH, Jang HD. Scopoletin and scopolin isolated from Artemisia iwayomogi suppress differentiation of osteoclastic macrophage RAW 264.7 cells by scavenging reactive oxygen species. J Nat Prod. 2013; 76(4):615-20.

Lee YK, Hong EY, Whang WK. inhibitory effect of chemical constituents isolated from Artemisia iwayomogi on polyol pathway and simultaneous quantification of major bioactive compounds. BioMed Res Int; 2017. https:// doi.org/10.1155/2017/7375615.

Li PX, Qing XC, Huang H, Xiao DL, Hong TC, Rong QZ. Inhibitory effects of cupferron on the monophenolase anddiphenolase activity of mushroom tyrosinase. Int J Bioch Cell Biol. 2003;35:1658-66.

Lu Y, Foo LY. Antioxidantand radical scavenging activities of polyphenols from apple pomance. J Food Chem. 2000;68:81-5.

Nguyen MT, Awale S, Tezuka Y, Tran QL, Watanabe H, Kadota S. Xanthine oxidase inhibitory activity of vietnamese medicinal plants. J Biol Pharm Bull. 2004; 27(9):1414-21.

Seo KS, Yun KW. Antioxidant activities of extracts from Artemisia capillaris T. and Artemisia iwayomogi K. used as Injin. Kor J Plant Res. 2008;21(4):292-8. 
Singh AK, Pathak V, Agrawal PK. Annphenone, a phenolic acetophenone from Artemisia annua. J Phytochemistry. 1997;44(3):555-7.

Urbatsch LE, Bacon JD, Mabry TJ. Flavonol methyl ethers from Chrysothamnus viscidiflorus. J Phytochemistry. 1975;14(10):2279-82.

Yamauchi R, Mukouyama D, Yamaguchi K. Screening of inhibitory activities for elastase and collagenase in the edible parts of fish and shellfish. J Fish Sci. 2000;66:798-800

\section{Publisher's Note}

Springer Nature remains neutral with regard to jurisdictional claims in published maps and institutional affiliations.

Submit your manuscript to a SpringerOpen ${ }^{\circ}$ journal and benefit from:

- Convenient online submission

- Rigorous peer review

- Open access: articles freely available online

- High visibility within the field

- Retaining the copyright to your article

Submit your next manuscript at $\boldsymbol{\wedge}$ springeropen.com 